\title{
HYDROCLIMATE VARIABILITY IN SNOW-FED RIVER SYSTEMS \\ Local Water Managers' Perspectives on Adapting to the New Normal
}

\author{
Kelley Sterle, Benjamin J. Hatchett, Loretta Singletary, and Greg Pohll
}

In the snow-fed Truckee-Carson river system, northern Sierra Nevada, water managers are adapting to the "new normal" climate inclusive of increased hydroclimate variability, warmer temperatures, and drought and flood extremes.

AFFILIATIONS: SteRLE-Global Water Center and Cooperative Extension, University of Nevada, Reno, Reno, Nevada; HatChetT-Division of Atmospheric Sciences, Desert Research Institute, and Western Regional Climate Center, Reno, Nevada; SINGLETARY - Department of Economics and Cooperative Extension, University of Nevada, Reno, Reno, Nevada; PoHLL-Division of Hydrologic Sciences, Desert Research Institute, Reno, Nevada CORRESPONDING AUTHOR: Kelley Sterle, ksterle@unr.edu

The abstract for this article can be found in this issue, following the table of contents.

DOI:10.II75/BAMS-D-18-003I.I

In final form 20 January 2019

(C2019 American Meteorological Society

For information regarding reuse of this content and general copyright information, consult the AMS Copyright Policy. precipitation phase from snow to rain (Knowles et al. 2006), altering snowpack dynamics, shifting peak streamflow timing, reducing groundwater recharge, and increasing winter and spring flooding (Mote et al. 2005; Stewart et al. 2005; McCabe et al. 2007; Jasechko et al. 2014; Trujillo and Molotch 2014; Dettinger et al. 2015; Harpold et al. 2017a). Warmer spring and summer temperatures further compound these "snow droughts" (Harpold et al. 2017b; Hatchett and McEvoy 2018) by increasing evapotranspiration rates and irrigation water demand (Hatchett et al. 2015). This presents critical challenges in managing seasonal water supply and demand engineered for stationary climate patterns (Milly et al. 2008; Georgakakos et al. 2014).

Conducting case study research in snow-fed river systems offers a unique opportunity to examine how hydroclimate variability alters water supply and influences local climate adaptation across diverse and competing water-use communities (McNeeley et al. 2016; Mills-Novoa et al. 2017; Sterle and Singletary 2017; Mostert 2018). Such climate adaptation 
strategies seek to moderate harm or exploit beneficial opportunities (Adger et al. 2005) in response to climatic stimuli, such as extreme droughts and floods, interannual variability, or changes in long-term average conditions (Smit et al. 2000). Strategies pursued are not exclusive to any one river system (Bierbaum et al. 2013) and ultimately relate to a system's hydrologic, socioeconomic, and ecological components, and its respective capacities to adapt (Adger et al. 2007; Moser and Boykoff 2013).

Implementation barriers that constrain or impede adaptation, however, may be site-specific (Moser and Ekstrom 2010; Eisenack et al. 2014). In the western United States, for example, enhancing and diversifying water supply to meet growing water demand may be limited by inherent water scarcity and overallocated water rights (Fuller and Harhay 2010; Padowski and Jawitz 2012; Owen 2014). Adaptation may be further constrained by lack of coordination (Burnham et al. 2016), stemming from longstanding conflict among diverse and competing water-use communities (Barnett et al. 2014; Coleman et al. 2016). In the context of climate change, adapting to snow droughts and atmospheric river (AR)-based flooding (e.g., Ralph et al. 2004, 2006; Konrad and Dettinger 2017) may be constrained by existing prior appropriation based water law and related institutional arrangements (Kates et al. 2012; Gallaher et al. 2013; Pulwarty and Maia 2015; McNeeley 2017). Revising such practices may be further constrained by climate uncertainty (Kates et al. 2012; Bierbaum et al. 2013) associated with human and natural system response to climate change (Liu et al. 2007; Van Loon et al. 2016), or the inability to downscale climate projections to scales useful for adaptation planning (Maurer and Hidalgo 2008; Vicuna et al. 2010; Maurer et al. 2014). Thus, adaptation to climate change is not one single strategy, but rather a set of diverse, intersecting strategies that consider both climate and nonclimatic stressors, such as population growth, ecological change, and evolving water management institutions (Thornton and Manasfi 2010).

A participatory research approach becomes useful in this context to characterize local climate adaptation and implementation barriers and to identify local science information needs (Morss et al. 2005; Engle 2012; McNeeley 2014; Pulwarty and Maia 2015; Burnham et al. 2016; Nava et al. 2016). Collaborative modeling that relies on the systematic and iterative interaction between researchers and key local stakeholders has the potential to harness local knowledge and perspectives useful to prioritize research activities (Langsdale et al. 2013; Beall King and Thornton 2016;
Singletary and Sterle 2017, 2018). These interactions seek to clarify stakeholders' mental models (Beall King and Thornton 2016), generate new knowledge of river system function under climate change (Moser and Ekstrom 2010; Cloutier et al. 2015; Prato 2015; Meadow et al. 2015), and advance applied climate and socio-hydrology research (Sivapalan et al. 2014; Klenk et al. 2015; Fazey et al. 2018; Mostert 2018).

Inspired by this growing body of climate adaptation research, this article reports new findings part of a 5-yr (July 2014-June 2019) collaborative modeling research program underway in the TruckeeCarson river system in California and Nevada of the western United States (Singletary and Sterle 2017, 2018). The program convenes an interdisciplinary research team of hydrologists, climatologists, and resources economists with key local water managers who represent the diverse and competing water-use communities in the river system. Annual interviews are conducted with the same local water managers to 1) assess shifts in climate adaptation strategies and implementation barriers over time (Sterle and Singletary 2017) and 2) identify and prioritize research activities presented at biannual Stakeholder Affiliate Group workshops. Research activities include developing climate scenarios (Dettinger et al. 2017) and simulating locally identified adaptation strategies using hydrologic and operations models tailored to the river system ${ }^{1}$ (Morway et al. 2016; Sterle et al. 2017).

Building on an already published comparative analysis of interview data collected during the 2015 and 2016 consecutive drought years (e.g., Sterle and Singletary 2017), we append and compare new data collected from a third wave of interviews following the 2017 historic wet year. We enhance this analysis by including an assessment of recent (2012-17) hydroclimate variability in a historical (last 120 years) and paleoclimate (greater than 120 years) context. In this article, we examine the following research questions: 1) How does recent hydroclimate variability compare to historical and paleoclimate climate records? 2) How do water management challenges faced during wet years compare to challenges faced during consecutive drought years? 3) How do local climate adaptation strategies and implementation barriers

\footnotetext{
${ }^{1}$ The hydrologic models include the Modular Three-Dimensional Finite-Difference Ground-Water Flow Model (MODFLOW), Precipitation Runoff Modeling System (PRMS), Coupled Groundwater and Surface-Water Flow Model (GSFLOW), and operations models include RiverWare and MODSIM.
} 


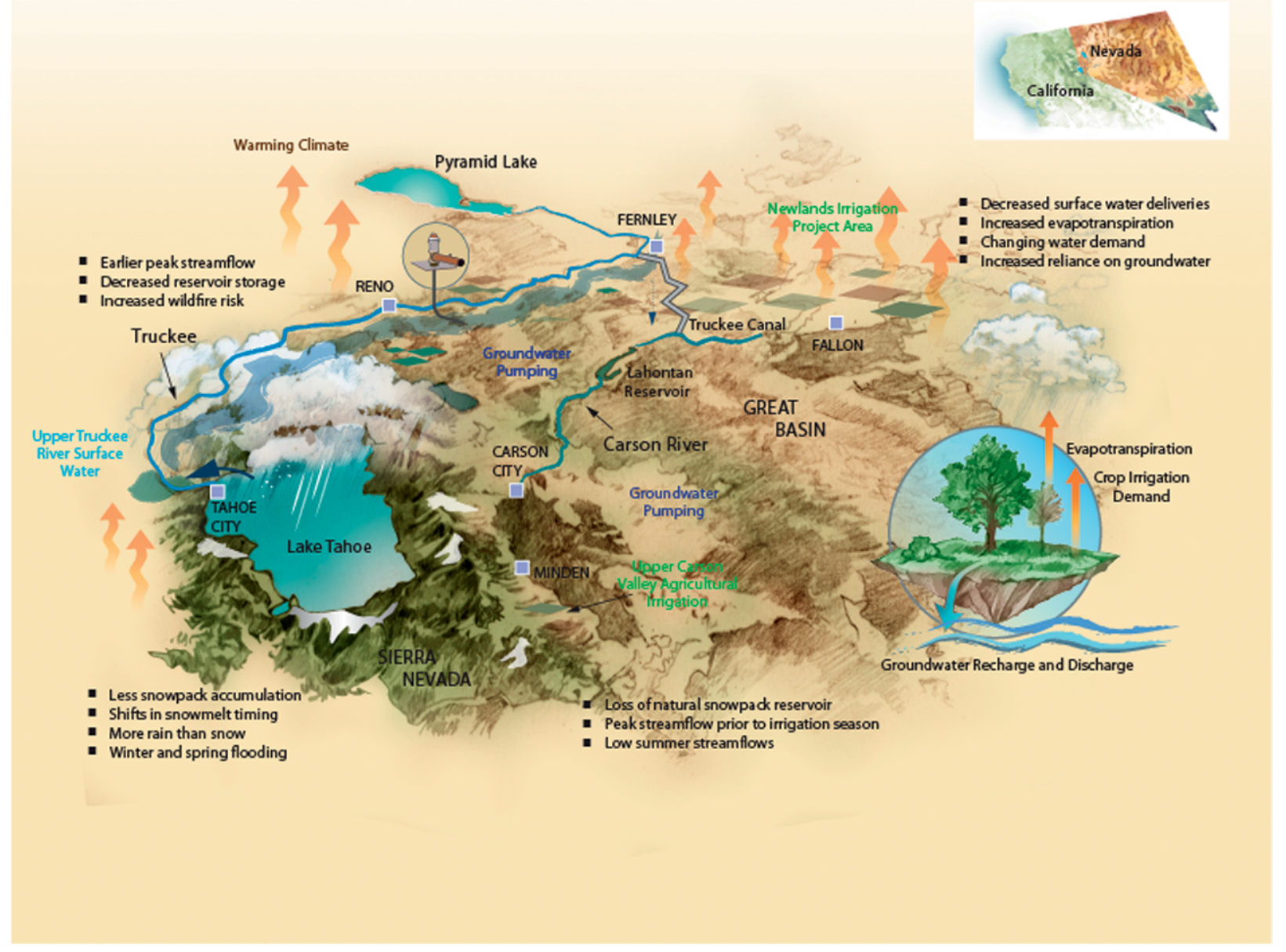

FIG. I. The Truckee-Carson river system of California and Nevada, noting the spatially variable impacts of a warmer climate described by local water managers (Sterle and Singletary 2017). Graphic design by Kelley Sterle and Ron Oden.

shift over time in the context of hydroclimate variability? 4) What science information is most useful to support long-term climate adaptation at the river system scale?

METHODS. The Truckee-Carson river system. The Truckee-Carson river system encompasses an area of $18,197 \mathrm{~km}^{2}$. The Truckee $(195 \mathrm{~km})$ and Carson $(211 \mathrm{~km})$ rivers originate in snow-dominated headwaters in the Sierra Nevada of eastern California and flow to terminal playa lakes in northwestern Nevada (Fig. 1). The 3,000-m-high Sierra Nevada creates a rain shadow effect resulting in a substantial climatic gradient in the river system, with an alpine and subalpine forested environment in the upper basin $(>1,700 \mathrm{~m})$ surrounding Lake Tahoe $\left(498 \mathrm{~km}^{2}\right)$ transitioning to arid desert in the terminal Great basin (1,200 m). Annual headwater precipitation exceeds $1,700 \mathrm{~mm}$, with nearly $90 \%$ above $1,800 \mathrm{~m}$ observed falling as snow between
November and April. The middle reaches receive less than $400 \mathrm{~mm}$ of precipitation annually on average, with lower reaches of the Carson River receiving less than $125 \mathrm{~mm}$. The majority of streamflow is generated by spring snowmelt runoff from April to July, with peak flows historically occurring in June, before declining to baseflow in September (U.S. Bureau of Reclamation 2015). Thirty-year (1981-2010) annual average temperatures for the region range from $8.8^{\circ}-20.5^{\circ} \mathrm{C}$ in the higher elevations in the headwaters to $19.4^{\circ}-34.7^{\circ} \mathrm{C}$ in the lower elevations near the system terminus (WRCC 2016).

Water supply to meet diverse demands is highly regulated through federal, tribal, state, and local prior appropriation based water allocation and related institutionalized agreements that typify western water law and assume a stationary climate (Milly et al. 2008). Local water utilities serving Reno-Sparks, the largest urban area (population: 425,000), satisfy water demand through conjunctive management 
of upstream Truckee River surface water reservoirs and regional groundwater aquifers. In contrast, Lake Tahoe communities (year-round resident population of 54,000 versus 300,000 on peak visitation days; ADE 2018), Carson City (population: 55,000), and other smaller communities in the river system rely almost entirely on groundwater. The network of upstream reservoirs is unique to the Truckee River, as the Carson River lacks upstream storage.

The majority of irrigated agriculture exists in the Upper Carson Valley (40,000 acres, $162 \mathrm{~km}^{2}$ ), where irrigators rely almost exclusively on snowmelt for water supply, and below Lahontan Reservoir in the Newlands Irrigation Project (57,000 acres, $\left.230 \mathrm{~km}^{2}\right)$. The Newlands Irrigation Project was the first Federal desert reclamation project in the United States (1906) and features the Truckee Canal, which facilitates an interbasin transfer of Truckee River surface flows away from the natural terminus at Pyramid Lake $\left(487 \mathrm{~km}^{2}\right)$. Located on sovereign reservation land, Pyramid Lake provides habitat for the endangered (Cui-ui) and threatened (Lahontan cutthroat trout) fish species. Diverted Truckee River surface flows, stored in Lahontan Reservoir, supplement Carson River flows to the Newlands Irrigation Project and also support riparian wetlands on the Stillwater National Wildlife Refuge (Wilds 2014).

Hydroclimate assessment for water years 20/2-17. To place hydroclimate variability observed during water years ${ }^{2} 2012-17$ into historical and paleoclimate contexts, the following station data were retrieved: 1) daily, quality-controlled precipitation, average temperature, and snow water equivalent (SWE) from the Carson Pass $(2,546 \mathrm{~m})$ and Tahoe City $(2,072 \mathrm{~m})$ Snowpack Telemetery (SNOTEL) stations acquired from the National Resources Conservation Service (NRCS 2018a) and the gridMet product (Abatzoglou 2013); 2) GPS-measured coastal precipitable water from Petaluma, California, as a proxy for AR conditions acquired from SuomiNet (Ware et al. 2000; UCAR 2018); 3) brightband-derived snow levels (White et al. 2010) from the NOAA Hydrometeorological Test Bed/California Department of Water Resources (DWR)-supported snow level radar located at Colfax, California, acquired from the Earth Systems Research Laboratory (ESRL 2018); 4) daily streamflow for the Truckee River at
Vista (site 10350000) and the Carson River, where flows were summed between the East Fork near Gardnerville (site 10309000) and West Fork at Woodfords (site 10310000) to provide an estimate of natural unimpaired flows above the Upper Carson Valley, acquired from the U.S. Geological Survey (USGS 2018); and 5) soil moisture percent acquired for Lovelock, Nevada, from the Natural Resource Conservation Service's Soil Climate Analysis Network (SCAN) (NRCS 2018b). Regional millennial- to centennial-scale paleoclimate context is provided through comparison of observed precipitation and temperature anomalies with those estimated by paleohydroclimate studies for past megadrought (Hatchett et al. 2015, 2016) and pluvial periods (Barth et al. 2016; Hatchett et al. 2018).

Interviews with local water managers. As part of the collaborative modeling research program (Singletary and Sterle 2017), the interdisciplinary research team conducts annual semi-structured interviews with the same $12 \mathrm{key}$ water managers who comprise a Stakeholder Affiliate Group that meets regularly and voluntarily. These managers were identified through a stakeholder analysis (Prell et al. 2009; Reed et al. 2009) and selected based on their local knowledge and perspectives as representatives of the urban $(n=3)$, agricultural $(n=4)$, environmental $(n=3)$, and regulatory $(n=2)$ water-use communities distributed geographically from headwaters to terminus.

Following the 2017 water year, researchers asked the same open-ended questions during one-hour semi-structured phone interviews with key water managers. ${ }^{3}$ Briefly, interview questions aimed to 1 ) understand water management challenges during the 2017 water year, 2) discuss existing and identify new adaptation strategies and implementation barriers faced, 3) gather input on locally identified alternative water management strategies to inform model simulations, and 4) identify science information needs to support long-term adaptation (Table 1). Researchers used an interview guide with probes for each question to clarify managers' responses. These included asking for examples specific to individual experiences and perspectives. To encourage more complete responses, question items (excluding probes) were emailed to each manager one week in advance of scheduled interviews.

\footnotetext{
${ }^{2}$ Water years, as opposed to calendar years, refers to 1 October to 30 September. Dates inclusive of the hydroclimate assessment are 1 Oct 2011 to 30 Sep 2017.

${ }^{3}$ Interview data collection and analyses consistently followed human subject research protocols that were reviewed and approved by the University of Nevada, Reno Office of Research Integrity.
} 
TABLE I. Phone interview questions administered in 2017 , including probes.

\section{Open-ended questions}

QI Can you briefly describe water management challenges faced during this most recent water year?

Probe: How did this historic wet year impact your organization's water management compared to previous drought years?

Q2 What is your organization currently doing to adapt to climate change? In implementing these strategies, do you face any barriers? Please explain.

Probe: Are any of these strategies/barriers new for your organization?

Q3 To help prioritize research and modeling activities, please rate the viability (viable, not viable, neutral) of each of the following alternative water management strategies as it pertains to the river system. Please explain your selection.

a. Reoperate Truckee River reservoirs to allow for earlier storage

b. Construct surface water reservoir on the Upper Carson River

c. Implement managed aquifer recharge in the Upper Carson Valley

Q4 What science information is most useful to support long-term adaptation?

Probe: Is there any other water- or climate-related information that might be useful?

Phone interviews were recorded using an audiosound laboratory at the University of Nevada, Reno and transcribed verbatim within $24 \mathrm{~h}$. Transcripts were then analyzed using constant comparison analysis (Glaser and Strauss 1999), a grounded theory approach useful to compare responses in order to examine shifts over time (Rossman and Rallis 2016; Thorne 2016; Creswell and Poth 2017). Responses were descriptively coded using a codebook that the authors developed for previous waves of interviews [for additional details on codebook development, see Sterle and Singletary (2017)]. This facilitated a comparison of the total number of managers who identified particular adaptation strategies and implementation barriers each year. The authors conducted an intercoder reliability assessment (Kurasaki 2000) to finalize codes assigned to each response, identify heterogeneities based on managers' locations and/or water management roles and responsibilities in the river system, and select quotes that illustrate managers' individual and shared perspectives.

RESULTS. In this section, we first report results of a hydroclimate assessment in the river system that places recent variability in a historical and paleoclimate context. Then, using a third wave of interview data, we 1) describe managers' water-management challenges following the historic wet year, 2) examine shifts in adaptation strategies and implementation barriers, and 3) present requested model simulations and additional science information useful to inform long-term adaptation. Water managers' direct quotes are presented to provide context, further illustrating variance across the water-use communities within the basin. Unless otherwise noted, "years" refers to water years.
Recent hydroclimate variability in a historical and paleoclimate context. Figure 2a presents annual SWE between 2012 and 2017 and temperature anomalies, calculated for each wet/cool season (November-March) and dry/warm season (June-September). The multiyear drought from 2012 to 2016 was notable for its low Sierra Nevada snowpack, measuring the lowest on record during 2015 and paired with anomalously warm wet season temperatures $\left(+2.5^{\circ} \mathrm{C}\right)$ (Fig. 2a) (Williams et al. 2015; Belmecheri et al. 2016; Mote et al. 2016). Precipitation anomalies were estimated to be similar to average conditions during centennialscale medieval megadroughts (Hatchett et al. 2015), a time when many western Great Basin lakes reached low levels (Stine 1994; Kleppe et al. 2011). While 2016 featured near-normal snowpack, warmer late winter and spring temperatures created late-onset warm snow drought conditions and an early peak in snowmelt runoff (as indicated by the SWE lines declining earlier than average) (Fig. 2a) (Hatchett and McEvoy 2018).

Average precipitation conditions spanning the twentieth century are estimated to be nearly as wet as any time during the past 4,000 years in the western Great Basin (Hatchett et al. 2015, 2018). Figures 2b-h illustrate hydroclimate conditions during 2017, the wettest year in the past century across much of the western Great Basin. An unprecedented number (53; $34 \%$ higher than average 1949-2017) of AR events made landfall along the California coast during 2017, with numerous landfalls during the October-February period (light blue bars in Figs. 2b-h). An estimated 33 ARs traversed the Sierra Nevada, bringing abundant precipitation to the rain shadow in northwestern Nevada (CNAP 2017). Many of these ARs had high-elevation snow levels (Fig. 2c), which 


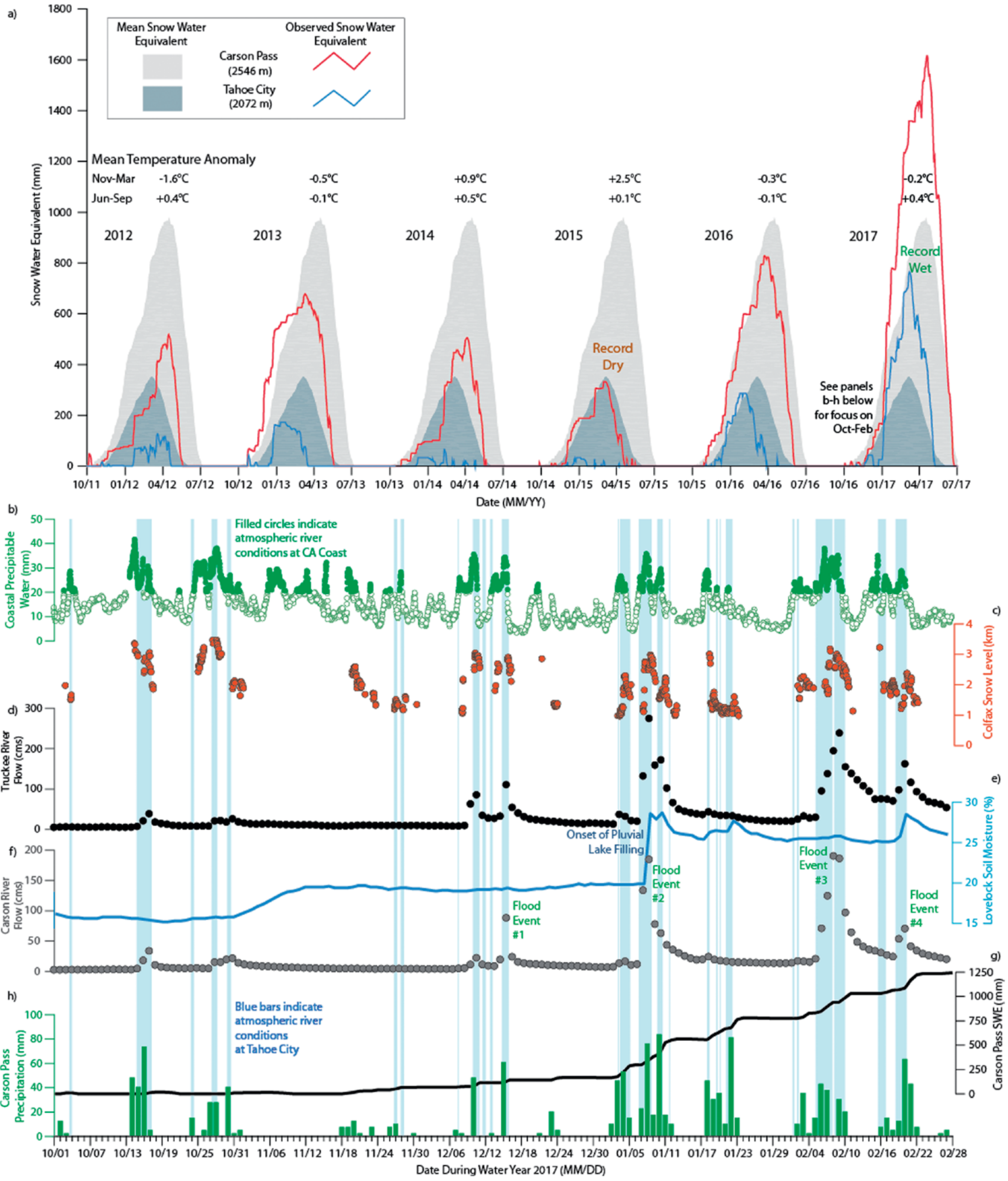

FIG. 2. Recent hydroclimate variability in the Truckee-Carson river system. (a) Water years 2012-17 snow water equivalent and mean temperature anomalies (relative to 1979-2017 long-term averages) measured at Carson Pass (red line) and Tahoe City (blue line). (b)-(h) Water year 2017 illustrating Oct-Feb precipitable water at the California coast and Carson Pass; snow levels at Colfax, California; streamflow for the Truckee and Carson Rivers; and soil moisture percent $(4-\mathrm{cm}$ depth) at Lovelock, Nevada. Light blue shaded bars correspond to atmospheric river conditions measured at Tahoe City based upon the AR catalog developed following Rutz et al. (2014). 
produced streamflow responses in both the Truckee (Fig. 2d) and Carson (Fig. 2h) rivers.

While the 2017 AR events helped to "bust" the 2012-16 drought (e.g., Dettinger 2013), they also contributed to cool season flooding, particularly on the Carson River (see flood event markers in Fig. 2f). From December to February, intense precipitation events (Fig. 2h) paired with high-elevation snow levels (Fig. 2c) melted existing snowpack. Associated flooding was observed on many smaller creeks and tributaries, inundating the lower-elevation valleys and increasing soil moisture (Fig. 2e). Notably, the second Carson River flood event (Fig. 2f) corresponds with the abrupt rise in soil moisture and the onset of pluvial lake filling in January. Although record precipitation was observed throughout the region, only the highest elevations $(>2,800 \mathrm{~m})$ observed record snowpack due to many storms having relatively high-elevation snow levels (Fig. 2c).

The precipitation anomalies observed during 2017, approximately $200 \%$ of normal, are comparable to precipitation estimated during the cooler deglacial period approximately 16,000 years ago when large pluvial lakes, such as Lake Lahontan, existed across the Great Basin (Munroe and Laabs 2013; Barth et al. 2016). Larger lakes, and thus wetter and cooler conditions, are interpreted to have occurred coincident with the penultimate deglaciation at approximately 150,000 years ago (Reheis 1999). Thus, precipitation anomalies during 2012-17 span the range of historical variability and also demonstrate precipitation magnitudes consistent with the wettest and driest conditions captured in the paleoclimate record spanning the past 150,000 years.

Water management challenges following the historic wet year. During interviews following the 2017 water year, managers explained that as compared to drought years, "wet years with flooding are more instantaneous, whereas drought is a very slow moving process", leading to a different set of "equally problematic" water management challenges. Managers across the river system emphasized the damage caused by the January and February AR events (Fig. 2f; flood events 2 and 3, respectively), describing how high flows washed out roads and surface water delivery diversions. Localized flooding also clogged stormdrains and inundated culverts, "wreaking havoc for our public works department." Additional negative impacts included weed infestation and increased soil erosion, particularly in areas with recent wildfire. Regardless of impacts experienced, several managers described climate in the region as "boom or bust" with water management a "real balancing act in order to stay ahead of the game."

Whether 2017 brought drought relief varied depending on managers' location and management role in the river system. For example, urban and regulatory managers described 2017 as a year of "just enough water" to recharge aquifers and fill surface water reservoirs allowing them to start with "a clean slate." Most environmental managers explained how flooding revitalized riparian areas and wetlands, and enhanced rangeland forage conditions. As one stated, "a few years of dry followed by one year of very wet...the transition was beautiful." For others, 2017 was a year of "too much water." For example, Upper Carson Valley agricultural managers noted how flood-inundated fields affected harvest timing: "We probably harvested 30 to 45 days later [late July to early August]." Because fields and diversion ditches were so inundated, "you couldn't really fix things or assess the damage until much later...until water [flows] finally dropped [in July]." For lower Truckee River environmental managers, flows were "too great" to manage downstream fisheries, damaging diversion infrastructure and weirs along the way. Agricultural managers at the system terminus did not declare drought relief, emphasizing how the combination of diverted floodwater and "hot [summer] temperatures" resulted in "still not enough water." As one manager explained, "those 100 degree $\left[{ }^{\circ} \mathrm{F}\right]$ summer days just kept coming and the evaporation was pretty incredible."

Shifts in adaptation strategies and implementation barriers. Adaptation strategies and implementation barriers described by managers in 2017 , as compared to 2015 and 2016, revealed increasing adaptation efforts, with some barriers emerging and others diminishing. Figure 3 presents adaptation strategies (Fig. 3a) and implementation barriers (Fig. 3b) described by water managers, appending the 2017 results to the existing 2015 and 2016 analyses (e.g., Sterle and Singletary 2017). As illustrated in Fig. 3a, we first observe that managers' efforts to manage for water demand diminished over time $(n=4)$. Following the drought of 2015, managers indicated that moving forward, water demand management must be paired with additional adaptation strategies (Sterle and Singletary 2017). For example, urban water managers described how climate data estimating the evaporative loss from surface water reservoirs could inform future revisions to drought planning.

Regardless of the drought relief (or lack thereof) experienced in 2017, managers explained that this 


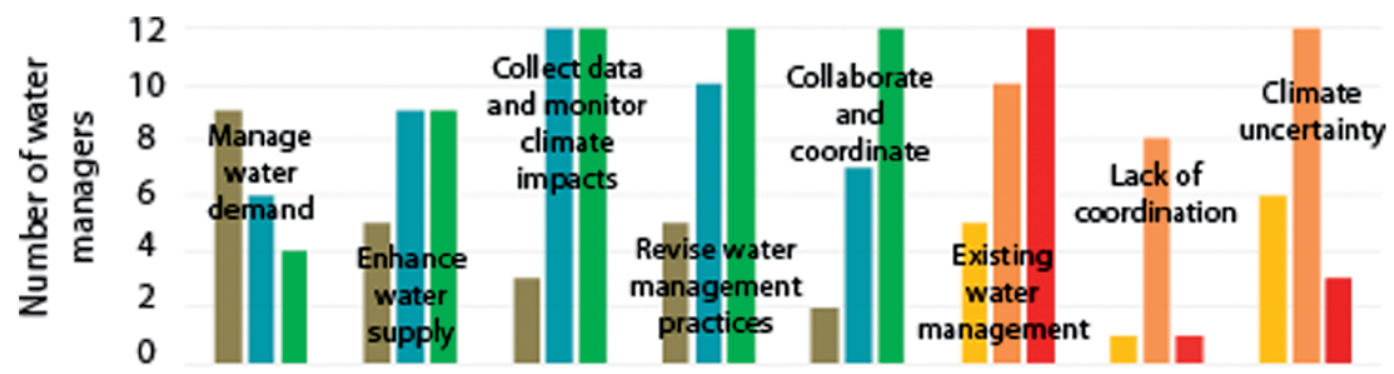

(a)

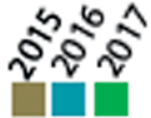

(a) Adaptation strategies

(b) Implementation barriers

(b)

FIG. 3. Shifts in (a) adaptation strategies and (b) implementation barriers over the 3-yr period (water years 2015, 2016, and 2017). To create this figure, coded data from 2017 were appended to 2015 and 2016 data presented in Sterle and Singletary (2017).

high-flow year did not "completely shift their [adaptation] strategies away from drought." As compared to previous drought years, the same number of water managers described efforts to: enhance water supply $(n=9)$ and collect data to monitor climate impacts $(n$ $=12$ ). Urban water managers' described new strategies to enhance and diversify water supply to "create a more robust [water] system prepared for [economic and municipal] growth and changing climate conditions." These managers described initiatives to meet emergent industrial water demand through reclaimed surface water and growing municipal demand through groundwater exploration and expanded water delivery networks. Meanwhile, agricultural and environmental managers described collaboration system-wide to "prioritize [water delivery] infrastructure [improvements] to be able to move water better during drought years." Regulatory water managers described hiring new staff to monitor groundwater change to improve their understanding of water supply and demand. Lake Tahoe water managers described using available climate information in local environmental planning to ensure that their new regulatory structure is "really flexible and adaptive to incorporate both extreme drought and flooding."

Additionally, as illustrated in Fig. 3a, comparatively more water managers $(n=12)$ described efforts to examine revisions to existing water management practices. That is, existing water management practices tied to stationary climate patterns were cited more often by water managers $(n=12)$ as a barrier in 2017 as compared to previous drought years (Fig. 3b). Truckee River urban managers, for example, cited upstream reservoir's fixed calendar date operations based on historical snowmelt and streamflow timing as "no longer applicable." Agricultural managers at the system terminus also noted how this shift in timing affects their date-based annual irrigation season determination: "We perform that [determination] in early spring, but if the forecasts are off, like they've been these past years, it causes us to revise that determination." As another manager explained, "It's the mismatch in timing that has us concerned." Carson River water managers discussed the need for new management strategies to address "the lack of long-term upstream storage options." As one urban manager explained, "Mother Nature's snowpack reservoir used to provide storage in the upper [Carson] watershed. We're having to bring someone in to look at future storage because we will need it when we lose snowpack."

All managers $(n=12)$ described the importance of improved collaboration and coordination necessary to facilitate adaptation (Fig. 3a), with a lack of coordination mentioned less often as a barrier compared to previous years (Fig. 3b). For example, communicating flood risk factors and coordinating mitigation measures in 2017 were critical to minimize flood impacts. For Truckee River managers, mandatory releases from flood control reservoirs coincident with AR events resulted in "dangerously high" Truckee River flows and standing water throughout the floodplain east of Reno-Sparks. Upstream water managers worked with downstream managers to closely monitor National Weather Service forecasts and to assess risks and damages to physical assets, including access roads and water conveyance and diversion infrastructure. Similarly, Carson River managers coordinated efforts across the system to mitigate "irreversible flood damage" by diverting flood water away from the city of Fallon (population: 8,500) to Carson Lake and the Carson Sink (see the sidebar "The Big Dig: Channeling 


\section{THE BIG DIG: CHANNELING FLOODWATERS TO THE GREAT BASIN}

The February snowmelt runoff forecast for the Upper Carson River basin indicated that Lahontan Reservoir (295,500 acre-feet, or $365 \mathrm{Mm}^{3}$ ) and the Newlands Irrigation Project would receive nearly 3 times its capacity- "a volume of water far greater than ever before. We knew we had a lot of water coming our way." On 10 February 2017, the Governor of Nevada declared a state of emergency. Beginning in February, urban, agricultural, environmental, and regulatory water managers and stakeholders along the Carson River and below Lahontan Reservoir met weekly to review forecasts and coordinate efforts under the Governor's emergency declaration. These diverse groups worked together to clear the Carson River channel of sandbars and debris, and prepare irrigation diversions and canals for precautionary drawdowns to manage Lahontan Reservoir levels. However, it was not enough. Managers realized that to mitigate "irreversible flood damage" a new diversion channel was needed.

A 17-mile and roughly 60-foot-wide channel, referred to as "the Big Dig," was built to divert approximately $3,000 \mathrm{cfs}(85 \mathrm{cms})$ away from the city of Fallon to Carson Lake, the
Stillwater National Wildlife Refuge, and eventually to its natural terminus at the Carson Sink (Fig. SBI). It was "very very concerted, a symphony of forecasting tools and personnel." As one manager reflected, "as a result of the Big Dig... we achieved roughly a four-fold increase in Carson River [flow capacity] from $325 \mathrm{cfs}(9 \mathrm{cms})$ to $1200 \mathrm{cfs}(34 \mathrm{cms})$. We moved as much as a million acre-feet of water through this system this year. And recall our [annual] demand for agricultural irrigation below Lahontan is only 200,000 acre-feet $\left(247 \mathrm{Mm}^{3}\right)$. We did this without hurting anybody in line."

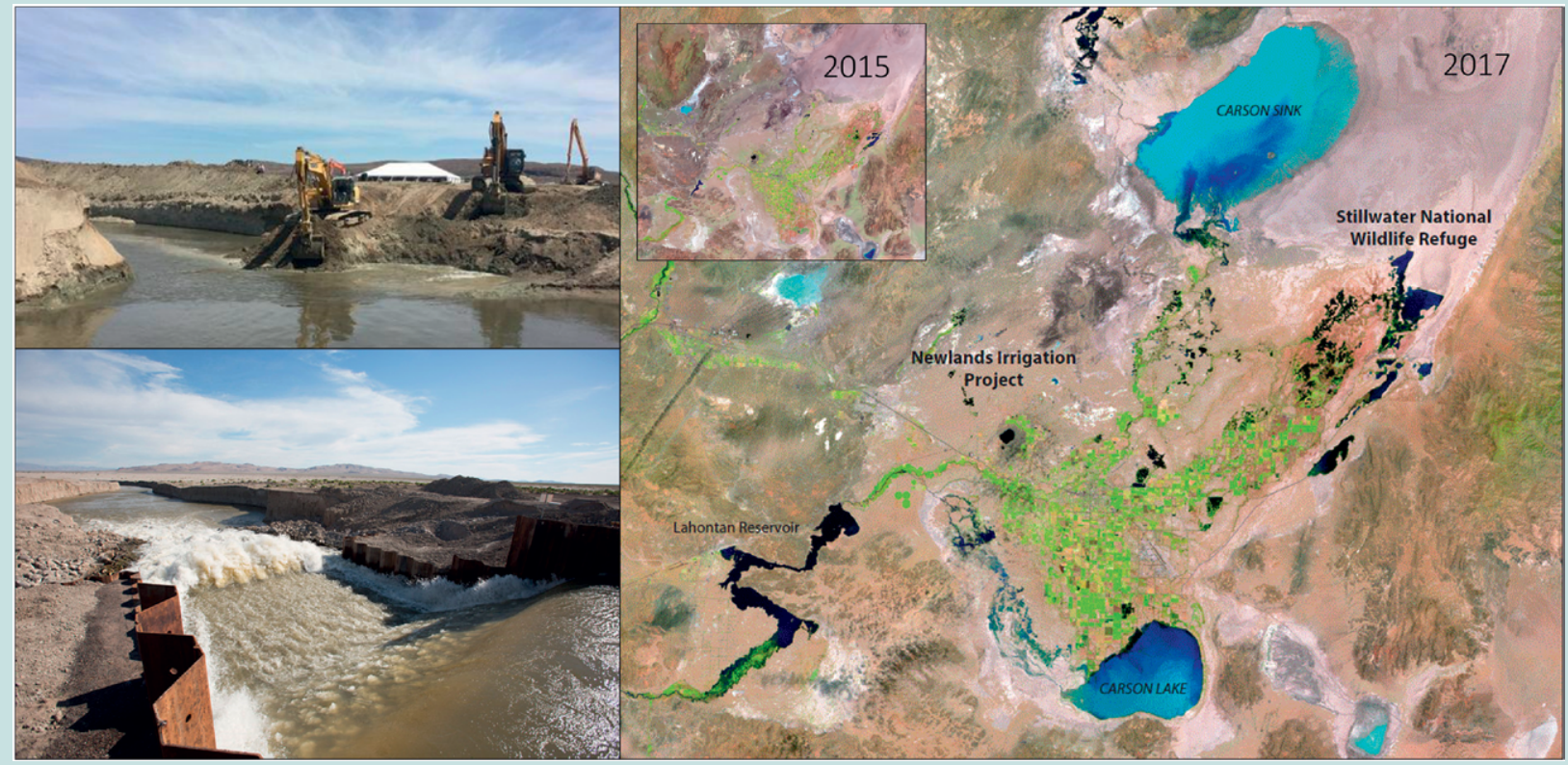

FIG. SBI. Lower Carson River and Lahontan Valley flood mitigation efforts. (top left) Big Dig excavation (Carlton 2017). (bottom left) Channel diverting flows from Lahontan Reservoir (Spillman 2017). (right) Newlands Irrigation Project, Sentinel 2 overpass from 6 Jun 2017. Right inset: Newlands Irrigation Project, Landsat 8 overpass from 29 Jul 2015. Overpass images courtesy of the Truckee-Carson Irrigation District.

floodwaters to the Great Basin"). These managers demonstrated how improved management coordination among diverse water-use communities, motivated by recent winter and spring flood events, can serve to accomplish common goals.

Compared to previous drought years, fewer managers $(n=3)$ referred to climate uncertainty as a barrier to adaptation (see Fig. 3b), exemplifying recent variability as the "new normal" climate for which they should plan-"we are headed toward more drought and more flood." Managers defined the new normal as "wetter weather patterns," "really dry years followed by really wet years," "winter floods with snowpack only in the highest elevations," "incredible evaporation amounts," and "warmer winters and hotter springs." To handle this "flashier climate," environmental and agricultural managers emphasized "natural solutions," explaining that in 2017 Upper Carson and Lower Truckee River floodplain restoration projects provided a "proof of concept." These managers noted that if upstream and downstream water users invest in continued restoration to reconnect the river to the floodplain, it will "give 
[the river system] a higher chance of success during extended periods of baseflow and more frequent flood events like we had this year." That is, continuing to protect the floodplain will help dissipate high flows and mitigate damage downstream.

Model simulations and science information to inform long-term adaptation. To help inform model simulations, researchers asked managers to rate the viability of three local water management strategies identified previously. Managers responded differently to each, and posed several follow-up questions to researchers (Fig. 4). Four managers $(n=12)$ rated reservoir reoperations on the Truckee River as viable, with five rating neutral, explaining that simulations of reoperations would help clarify how earlier storage might enhance water supply across the system. As one manager said, "These [operating] rules were set in 1980 and based on the previous 30 years of hydrology...the data are 60-70 years old. It just doesn't work anymore."

In discussing strategies on the Carson River, managers described Carson River storage options like managed aquifer recharge (MAR) that are "in the ground" as comparatively more viable than building surface water reservoirs. Four managers $(n=12)$ rated MAR as viable, compared to zero managers rating a reservoir on the Upper Carson River as viable (Sterle et al. 2018, manuscript submitted to J. Water Resour. Plann. Manage.). As one manager said, "This is no longer the age of dam construction. I'm pulling my teeth...it's just not going to happen." Researchers described MAR as having the potential to enhance long-term groundwater sustainability if excess flows during high water years (such as 2017) were diverted to artificially recharge aquifers (Niswonger et al. 2017). Regardless of rating, however, all managers
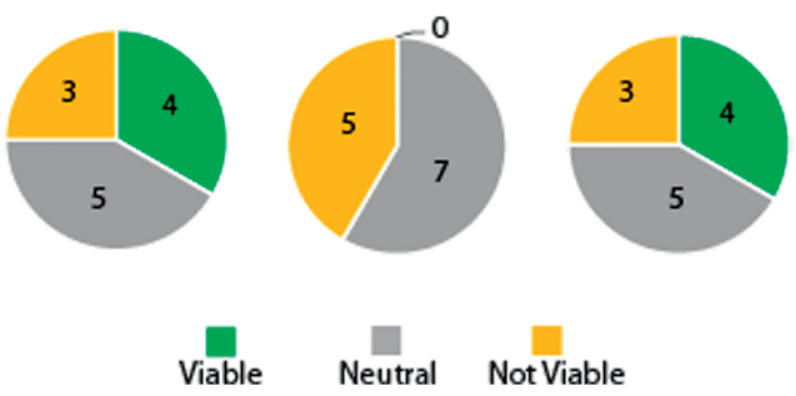

FIG. 4. Viability rating of each of three locally identified alternatives to water management $(n=12)$ : (a) reoperate Truckee River reservoirs to allow for earlier storage, (b) construct surface water reservoir on the Upper Carson River, and (c) implement managed aquifer recharge in the Upper Carson valley. cautioned that while MAR may be physically feasible, this strategy is prohibitive under existing prior appropriation-based water law (i.e., the Alpine Decree). Managers requested that researchers prioritize simulations of MAR to help clarify the following: "Where in the Upper Carson Valley could you do this to ensure long-term water storage? How could this work under existing water law? What would need to be changed? What are the implications for downstream users, including flows diverted from the Truckee River?" As one manager stated, "Modeling is the only real tool we have to assess whether it's [adaptation] really going to work or not." Managers encouraged researchers to examine these strategies using hypothetical yet plausible climate scenarios similar to recently observed conditions (Dettinger et al. 2017).

Managers described additional science-based information useful to support their long-term adaptation planning. This included support in translating climate change projections to local planning time scales (i.e., 5-10 years) and analyses to reaffirm to what extent recently observed conditions are indicative of the new normal climate expected for the region. For example, regulatory managers asked "What does a $2^{\circ} \mathrm{C}$ warmer climate mean for the $1-\mathrm{h}$ 20 -yr storm criteria, or other similar [engineering] project design standards?" Environmental managers requested similar climate information useful to revise water quality targets, including total maximum daily load (TMDL) and Lake Tahoe clarity (see the sidebar "Lake Tahoe: An indicator of change").

DISCUSSION. Recent hydroclimate variability across the Truckee-Carson river system provided a unique opportunity to assess the significance of these climate conditions in order to better interpret shifts in local water managers' local climate adaptation strategies and implementation barriers. Within a 6-yr period (water years 2012-17), the range of historical variability was defined by a very dry period and a very wet period (Fig. 2a), with both wet and dry extremes characteristic of the range of hydroclimate magnitudes on centennial to millennial time scales (Hatchett et al. 2015; Barth et al. 2016). The extreme variability observed during this period is consistent with abundant AR landfalls and record wet precipitation (2017) and conversely, the rarity of AR landfalls (2012-15), which drive hydroclimate variability in the Truckee-Carson river system (Dettinger et al. 2011; Rutz et al. 2014). However, as evidenced by geomorphic indicators, such as terminal lake levels and the presence of terrestrial plants in present-day water 
bodies (Hatchett 2018), past climate extremes were also characterized by centennial-scale persistence of drought conditions.

A significant finding from our comparison of a third wave of interview data collected following the 2017 water year reveals that despite a historic wet year and regardless of level of drought relief experienced, managers continued adaptation efforts outlined during previous drought years. Similar to case studies in snow-fed river systems elsewhere, water managers described motivation to continue their adaptation efforts as climate conditions altered the timing and availability of water supply (Alauddin and Sarker 2014; Roco et al. 2014; Feola et al. 2015; Yung et al. 2015; Doll et al. 2017), exacerbated existing management challenges, and revealed limitations in existing water management practices (Travis 2014; BerrangFord et al. 2011; Bierbaum et al. 2013). Comparison of these data also reveal that over this time period, managers referred to climate uncertainty as an implementation barrier less often illustrating a sense of acceptance that they have already experienced the "new normal" conditions for which they should be planning.

To validate managers' perspectives on the new normal climate, we extended the hydroclimate assessment to examine whether recent variability is indicative of projected future climate. While substantial interannual precipitation variability exists in the region (Dettinger et al. 2011; Ralph and Dettinger 2012; Dettinger 2016), the recent 2012-17 period illustrates the range of hydroclimate extremes anticipated to intensify under climate change (Cayan et al. 2010; Swain et al. 2018; Dettinger et al. 2018). Climate model projections suggest an increase in AR strength (Lavers et al. 2015; Espinoza et al. 2018) and heavy precipitation days (Pierce et al. 2013) as well as an increase in dry days (Polade et al. 2014). Should these projections be realized, it would result in increased hydroclimate variability, particularly when combined with background increases in temperature, further enhancing drought impacts (Cook et al. 2015) and decreasing water supply. Water supply will be impacted further by shifts in precipitation phase from snow to rain (Hatchett et al. 2017) that alter streamflow (Berghuijs et al. 2014) and temperature and humidity changes that influence snowmelt processes (Barnhart et al. 2016; Harpold and Brooks 2018). The likely scenario of persistent drought punctuated by occasional extreme wet years superimposed upon warming background temperatures (e.g., Hatchett et al. 2016) will necessitate adaptive strategies to optimize water availability and mitigate winter and spring flooding.

\section{LAKE TAHOE:}

\section{AN INDICATOR OF CHANGE}

The headwaters of the Truckee River, Lake Tahoe $\left(191 \mathrm{mi}^{2}, 490 \mathrm{~km}^{2}\right)$, is a deep $(1000 \mathrm{ft}, 300 \mathrm{~m})$ freshwater lake sitting at $1900 \mathrm{~m}$ in the Sierra Nevada. The lake is known for its iconic clarity and world-class tourism, visited by roughly three million people per year. Climate change poses a different set of challenges for Lake Tahoe water managers, focused less on water supply and more on increased wildfires and deteriorating water quality. As one manager reflected, "What's interesting is in the dry 2015 year, we had warmer lake [Tahoe] temperatures and little runoff, which was warm when it entered the lake. So, we ended up with diminished clarity due to increased algal blooms because of this warmer water. Then, in 2016, the 'normal' snowpack year, we had more warm temperatures and really bad summer clarity due to algal blooms. But we realized, the species of algae has changed. So, what is our new summer clarity target number?"

Also unique to Lake Tahoe water managers is maintaining an economically viable community based on seasonal tourism and upholding a public perception that "Tahoe is a good vacation destination even if high water years means less beach and drought means less skiing." Recent snow droughts have inserted water availability into discussions, not for environmental habitat or municipal uses (which is groundwater sourced), but for the ski industry: "They use a ton of water to make snow...will it always be available?"

Improved communication and coordination may have occurred as a result of 2017 flooding conditions that required cooperation among otherwise competing water-use interests (see Fig. 3), resulting in managers describing lack of coordination as a barrier less often. We speculate that improvements may also be the result of manager's participation in the larger collaborative modeling research program that brings together managers from diverse water-use communities with longstanding and historical water conflicts (Singletary and Sterle 2017). Biannual Stakeholder Affiliate Group workshops are designed to create a forum for social learning and information exchange (Allen et al. 2017; Dilling and Berggren 2015) where key water managers and researchers review interview results and prioritize model simulations that examine viable strategies to adapt to salient hydroclimate conditions. Simulations include exploring water supply benefits under earlier Truckee River reservoir storage (Sterle et al. 2018, manuscript submitted to J. Water Resour. Plann. Manage.) and MAR during wet years to increase groundwater sustainability in the upper Carson River valley (Niswonger et al. 2017). 
As this article demonstrates, the integration of local knowledge with applied climate research was advantageous to contextualize shifts in managers' adaptation strategies and implementation barriers over the 3-year period. For example, a closer look at temperatures during the spring of 2016 affirmed a late-onset snow drought and earlier spring snowmelt (Fig. 2a). These quantitative data help to explain why in 2016, despite near-normal snowpack and water supply forecasts, more local water managers identified climate uncertainty as an adaptation barrier as compared to 2015 (Sterle and Singletary 2017). Following the 2017 water year, additional managers cited existing water management practices as a barrier to adjusting operational rules to maximize storage during high-flow years (Fig. 3b). An affirmation that hydroclimate conditions are indicative of projected future climate conditions helped to validate managers' perspectives that recently observed conditions exemplify the new normal, while also providing inputs useful to their local long-term adaptation planning.

Further extension of these interviews to include a fourth wave of data collection following the 2018 water year will help to identify system-wide adaptation tipping points, defined as points where the magnitude of climate change requires new management strategies (Kwadijk et al. 2010). Quantifying these tipping points can help researchers further understand the coupled human-water system and develop decision-making criteria to advance hydrologic and operations model simulations (Voinov and Bousquet 2010; Voinov et al. 2016; Blair and Buytaert 2016; Mostert 2018).

CONCLUDING REMARKS. Increased hydroclimate variability in snow-fed river systems is expected to become more commonplace under continued warming (Polade et al. 2017; Swain et al. 2018). Between water years 2012 and 2017, hydroclimate variability observed in the Truckee-Carson river system coincided with measurable shifts in local climate adaptation strategies and implementation barriers. Managers in such delicately balanced river systems will need to continue exploring adaptation and related management strategies that enhance water availability during times of drought and manage flooding risk during heavy precipitation years (Baker et al. 2018). Truckee-Carson river system managers and researchers will continue to collaborate to assess the viability of locally identified alternative water management catered for nonstationary climate.

Our research contributes to a growing body of climate adaptation literatures and illustrates the potential outcomes of interdisciplinary research that integrates local knowledge with applied climate research. As a result, researchers can prioritize research and modeling activities to ensure results are useful (Dessai et al. 2005; Meadow et al. 2015; Parris et al. 2016; Prokopy et al. 2017). We encourage participatory and interdisciplinary research approaches in other snow-fed river systems to support adaptive water management under climate change (Klenk et al. 2015; Verkerk et al. 2017; Fazey et al. 2018).

ACKNOWLEDGMENTS. The authors acknowledge local water managers across the Truckee-Carson river system who contributed substantively to this study. Research was funded by the National Science Foundation (NSF) Division of Earth Sciences Water Sustainability and Climate program (Award 1360506), the U.S. Department of Agriculture (USDA) National Institute of Food and Agriculture (NIFA) (Award 2014-67003-22105), the U.S. Geological Survey (USGS) (Grant G14AP00076), and the Southwest Climate Adaptation Science Center (SWCASC). Its contents are solely the responsibility of the authors and do not necessarily represent the official views of the USGS. This manuscript is submitted for publication with the understanding that the U.S. government is authorized to reproduce and distribute reprints for governmental purposes. We thank the editor and three anonymous reviewers for constructive comments that improved this manuscript.

\section{REFERENCES}

Abatzoglou, J. T., 2013: Development of gridded surface meteorological data for ecological applications and modelling. Int. J. Climatol., 33, 121-131, https://doi .org/10.1002/joc.3413.

ADE, 2018: Measuring for prosperity: Community and economic indicators for the Lake Tahoe Basin. Applied Development Economics, 100 pp., https:// tahoeprosperity.org/tahoe-data/.

Adger, W. N., N. W. Arnell, and E. L. Tompkins, 2005: Successful adaptation to climate change across scales. Global Environ. Change, 15, 77-86, https:// doi.org/10.1016/j.gloenvcha.2004.12.005.

— , and Coauthors, 2007: Assessment of adaptation practices, options, constraints and capacity. Climate Change 2007: Impacts, Adaptation, and Vulnerability. M. L. Parry et al., Eds., Cambridge University Press, 717-743.

Alauddin, M., and M. A. R. Sarker, 2014: Climate change and farm-level adaptation decisions and strategies in drought-prone and groundwater-depleted areas of Bangladesh: An empirical investigation. Ecol. Econ., 106, 204-213, https://doi.org/10.1016/j.ecolecon .2014.07.025. 
Allen, E., J. Stephens, G. Yorgey, C. Kruger, S. Ahamed, and J. Adam, 2017: Climate science information needs among natural resource decision-makers in the Northwest US. Climate Serv., 5, 11-22, https:// doi.org/10.1016/j.cliser.2017.03.002.

Baker, Z., J. Ekstrom, and L. Bedsworth, 2018: Climate information? Embedding climate futures within temporalities of California water management. Environ. Sociol., 4, 419-433, https://doi.org/10.1080/2325104 2.2018.1455123.

Barnett, J., S. Graham, C. Mortreux, R. Fincher, E. Waters, and A. Hurlimann, 2014: A local coastal adaptation pathway. Nat. Climate Change, 4, 11031108, https://doi.org/10.1038/nclimate2383.

Barnett, T. P., J. C. Adam, and D. P. Lettenmaier, 2005: Potential impacts of a warming climate on water availability in snow-dominated regions. Nature, 438, 303-309, https://doi.org/10.1038/nature04141.

Barnhart, T. B., N. P. Molotch, B. Livneh, A. Harpold, J. F. Knowles, and D. Schneider, 2016: Snowmelt rate dictates streamflow. Geophys. Res. Lett., 43, 8006-8016, https://doi.org/10.1002/2016GL069690.

Barth, C., D. P. Boyle, B. J. Hatchett, S. D. Bassett, C. B. Garner, and K. D. Adams, 2016: Late Pleistocene climate inferences from a water balance model of Jakes Valley, Nevada (USA). J. Paleolimnol., 56, 109-122, https://doi.org/10.1007/s10933-016-9897-z.

Beall King, A., and M. Thornton, 2016: Staying the course: Collaborative modeling to support adaptive and resilient water resource governance in the inland Northwest. Water, 8, 232, https://doi.org/10.3390/w8060232.

Belmecheri, S., F. Babst, E. R. Wahl, D. W. Stahle, and V. Trouet, 2016: Multi-century evaluation of Sierra Nevada snowpack. Nat. Climate Change, 6, 2-3, https://doi.org/10.1038/nclimate2809.

Berghuijs, W. R., R. A. Woods, and M. Hrachowitz, 2014: A precipitation shift from snow towards rain leads to a decrease in streamflow-supplement. Nat. Climate Change, 4, 583-586, https://doi.org/10.1038 Inclimate2246.

Berrang-Ford, L., J. D. Ford, and J. Paterson, 2011: Are we adapting to climate change? Global Environ. Change, 21, 25-33, https://doi.org/10.1016/j.gloenvcha .2010.09.012.

Bierbaum, R., and Coauthors, 2013: A comprehensive review of climate adaptation in the United States: More than before, but less than needed. Mitigation Adapt. Strategies Global Change, 18, 361-406, https:// doi.org/10.1007/s11027-012-9423-1.

Blair, P., and W. Buytaert, 2016: Socio-hydrological modelling: A review asking "why, what and how?" Hydrol. Earth Syst. Sci., 20, 443-478, https://doi.org/10.5194 /hess-20-443-2016.
Burnham, M., Z. Ma, J. Endter-Wada, and T. Bardsley, 2016: Water management decision making in the face of multiple forms of uncertainty and risk. J. Amer. Water Resour. Assoc., 52, 1366-1384, https://doi .org/10.1111/1752-1688.12459.

Carlton, J., 2017: States brace for flooding as Sierra's historic snowpack melts. Wall Street Journal, 15 June, www.wsj.com/amp/articles/states-brace -for-flooding-as-sierras-historic-snowpack-melts -1497531600 ? responsive $=\mathrm{y} \&$ tesla $=\mathrm{y}$.

Cayan, D. R., T. Das, D. W. Pierce, T. P. Barnett, M. Tyree, and A. Gershunov, 2010: Future dryness in the southwest US and the hydrology of the early 21st century drought. Proc. Natl. Acad. Sci. USA, 107, $21271-$ 21 276, https://doi.org/10.1073/pnas.0912391107.

Cloutier, G., F. Joerin, C. Dubois, M. Labarthe, C. Legay, and D. Viens, 2015: Planning adaptation based on local actors' knowledge and participation: A climate governance experiment. Climate Policy, 15, 458-474, https://doi.org/10.1080/14693062.2014.937388.

CNAP, 2017: Precipitation water year 2017. CaliforniaNevada Climate Applications Program, 2 pp., https:// scripps.ucsd.edu/programs/cnap/twopagers/.

Coleman, J. M. A., F. S. Sosa-Rodriguez, L. D. Mortsch, and P. J. Deadman, 2016: Assessing stakeholder impacts and adaptation to low water-levels: The TrentSevern waterway. Climatic Change, 134, 115-129, https://doi.org/10.1007/s10584-015-1524-x.

Cook, B. I., T. R. Ault, and J. E. Smerdon, 2015: Unprecedented 21st century drought risk in the American Southwest and Central Plains. Sci. Adv., 1, e1400082, https://doi.org/10.1126/sciadv.1400082.

Creswell, J. W., and C. N. Poth, 2017: Qualitative Inquiry and Research Design: Choosing Among Five Approaches. 4th ed. SAGE Publications, $488 \mathrm{pp}$.

Dessai, S., X. Lu, and J. S. Risbey, 2005: On the role of climate scenarios for adaptation planning. Global Environ. Change, 15, 87-97, https://doi.org/10.1016/j .gloenvcha.2004.12.004.

Dettinger, M. D., 2013: Atmospheric rivers as drought busters on the U.S. West Coast. J. Hydrometeor., 14, 1721-1732, https://doi.org/10.1175/JHM-D-13-02.1.

_ 2016: Historical and future relations between large storms and droughts in California. San Francisco Estuary Watershed Sci., 14 (1), https://doi.org/10.15447 /sfews.2016v14iss2art1.

— , F. M. Ralph, T. Das, P. J. Neiman, and D. R. Cayan, 2011: Atmospheric rivers, floods and the water resources of California. Water, 3, 445-478, https://doi .org/10.3390/w3020445.

— B. Udall, and A. Georgakakos, 2015: Western water and climate change. Ecol. Appl., 25, 2069-2093, https://doi.org/10.1890/15-0938.1. 
_ , K. Sterle, K. Simpson, L. Singletary, M. McCarthy, and K. Fitzgerald, 2017: Climate scenarios for the Truckee-Carson river system (SP-17-05). University of Nevada Cooperative Extenson, 12 pp., www.unce .unr.edu/publications/.

_ - and Coauthors, 2018: Sierra Nevada Summary Report: California's Fourth Climate Change Assessment, Rep. SUM-CCCA5-2018-004, 94 pp., www .climateassessment.ca.gov/regions/docs/20180827 -SierraNevada.pdf.

Dilling, L., and J. Berggren, 2015: What do stakeholders need to manage for climate change and variability? A document-based analysis from three mountain states in the Western USA. Reg. Environ. Change, 15, 657-667, https://doi.org/10.1007/s10113-014-0668-y.

Doll, J. E., B. Petersen, and C. Bode, 2017: Skeptical but adapting: What Midwestern farmers say about climate change. Wea. Climate Soc., 9, 739-751, https:// doi.org/10.1175/WCAS-D-16-0110.1.

Eisenack, K., S. C. Moser, E. Hoffmann, R. J. T. Klein, C. Oberlack, A. Pechan, M. Rotter, and C. J. A. M. Termeer, 2014: Explaining and overcoming barriers to climate change adaptation. Nat. Climate Change, 4, 867-872, https://doi.org/10.1038/nclimate2350.

Engle, N. L., 2012: Adaptation bridges and barriers in water planning and management: Insight from recent extreme droughts in Arizona and Georgia. J. Amer. Water Resour. Assoc., 48, 1139-1150, https:// doi.org/10.1111/j.1752-1688.2012.00676.x.

Espinoza, V., D. E. Waliser, B. Guan, D. A. Lavers, and F. M. Ralph, 2018: Global analysis of climate change projection effects on atmospheric rivers. Geophys. Res. Lett., 45, 4299-4308, https://doi .org/10.1029/2017GL076968.

ESRL, 2018: Snow level radar. Earth Systems Research Laboratory, accessed 2 April 2018, www.esrl.noaa .gov/psd/data/obs/sitemap/psdmapdata/mapdata.php.

Fazey, I., and Coauthors, 2018: Ten essentials for action-oriented and second order energy transitions, transformations and climate change research. Energy Res. Soc. Sci., 40, 54-70, https://doi.org/10.1016/j .erss.2017.11.026.

Feola, G., A. M. Lerner, M. Jain, M. J. F. Montefrio, and K. A. Nicholas, 2015: Researching farmer behaviour in climate change adaptation and sustainable agriculture: Lessons learned from five case studies. J. Rural Stud., 39, 74-84, https://doi.org/10.1016/j .jrurstud.2015.03.009.

Fuller, A. C., and M. O. Harhay, 2010: Population growth, climate change and water scarcity in the Southwestern United States. Amer. J. Environ. Sci., 6, 249-252, https://doi.org/10.3844/ajessp .2010 .249 .252 .
Gallaher, S., T. Heikkila, W. Patterson, V. Frank, and C. Weible, 2013: Adapting water policy tools to new issues: Lessons from Colorado's experience over time. Water Policy, 15, 43-60, https://doi.org/10.2166 /wp.2012.027.

Georgakakos, A., P. Fleming, M. Dettinger, C. PetersLidard, T. Richmond, K. Reckhow, K. White, and D. Yates, 2014: Water resources. National Climate Assessment, J. M. Melillo, T. C. Richmond, and G. W. Yohe, Eds. U.S. Global Change Research Program, 69-112, http://nca2014.globalchange.gov/report /sectors/water.

Glaser, B. G., and A. L. Strauss, 1999: The Discovery of Grounded Theory: Strategies for Qualitative Research. Routledge, 282 pp.

Harpold, A., and P. D. Brooks, 2018: Humidity determines snowpack ablation under a warming climate. Proc. Natl. Acad. Sci. USA, 115, 1215-1220, https:// doi.org/10.1073/pnas.1716789115.

—, M. Kaplan, P. Z. Klos, T. Link, J. P. McNamara, S. Rajagopal, R. Schumer, and C. M. Steele, 2017a: Rain or snow: Hydrologic processes, observations, prediction, and research needs. Hydrol. Earth Syst. Sci., 21, 1-22, https://doi.org/10.5194/hess-21-1-2017.

- - M. Dettinger, and S. Rajagopal, 2017b: Defining snow drought and why it matters. Eos, Trans. Amer. Geophys. Union, 98, https://doi.org /10.1029/2017EO068775.

Hatchett, B. J., 2018: Fingerprints of the thermal equator. Nat. Geosci., 11, 387, https://doi.org/10.1038 /s41561-018-0129-1.

- , and D. J. McEvoy, 2018: Exploring the origins of snow drought in the northern Sierra Nevada, California. Earth Interact., 22, https://doi.org/10.1175 /EI-D-17-0027.1.

- D. P. Boyle, A. E. Putnam, and S. D. Bassett, 2015: Placing the 2012-2015 California-Nevada drought into a paleoclimatic context: Insights from Walker Lake, California-Nevada, USA. Geophys. Res. Lett., 42, 8632-8640, https://doi .org/10.1002/2015GL065841.

,-- C. B. Garner, M. L. Kaplan, A. E. Putnam, and S. D. Bassett, 2016: Magnitude and frequency of wet years under a megadrought climate in the western Great Basin, USA. Quat. Sci. Rev., 152, 197-202, https://doi.org/10.1016/j.quascirev.2016.09.017.

_, B. Daudert, C. B. Garner, N. S. Oakley, A. E. Putnam, and A. B. White, 2017: Winter snow level rise in the northern Sierra Nevada from 2008 to 2017. Water, 9, 899, https://doi.org/10.3390/w9110899.

— D. P. Boyle, C. B. Garner, M. L. Kaplan, S. D. Bassett, and A. E. Putnam, 2018: Sensitivity of a western Great Basin terminal lake to winter northeast 
Pacific storm track activity and moisture transport. From Saline to Freshwater: The Diversity of Western Lakes in Space and Time, S. W. Starratt and M. R. Rosen, Eds., Geological Society of America, 67-79.

IPCC, 2014: Climate Change 2014: Synthesis Report. R.

K. Pachauri and L. A. Meyer, Eds., IPCC, 151 pp.

Jasechko, S., S. J. Birks, T. Gleeson, Y. Wada, P. J. Fawcett,

Z. D. Sharp, J. J. McDonnell, and J. M. Welker, 2014:

The pronounced seasonality of global groundwater recharge. Water Resour. Res., 50, 8845-8867, https:// doi.org/10.1002/2014WR015809.

Kates, R. W., W. R. Travis, and T. J. Wilbanks, 2012: Transformational adaptation when incremental adaptations to climate change are insufficient. Proc. Natl. Acad. Sci. USA, 109, 7156-7161, https://doi .org/10.1073/pnas.1115521109.

Klenk, N. L., K. Meehan, S. L. Pinel, F. Mendez, P. T. Lima, and D. M. Kammen, 2015: Stakeholders in climate science: Beyond lip service? Science, 350, 743-744, https://doi.org/10.1126/science.aab1495.

Kleppe, J. A., D. S. Brothers, G. M. Kent, F. Biondi, S. Jensen, and N. W. Driscoll, 2011: Duration and severity of medieval drought in the Lake Tahoe Basin. Quat. Sci. Rev., 30, 3269-3279, https://doi.org/10.1016/j .quascirev.2011.08.015.

Knowles, N., M. D. Dettinger, and D. R. Cayan, 2006: Trends in snowfall versus rainfall in the western United States. J. Climate, 19, 4545-4559, https://doi .org/10.1175/JCLI3850.1.

Konrad, C. P., and M. D. Dettinger, 2017: Flood runoff in relation to water vapor transport by atmospheric rivers over the western United States, 1949-2015. Geophys. Res. Lett., 44, $11456-11$ 462, https://doi .org/10.1002/2017GL075399.

Kurasaki, K. S., 2000: Intercoder reliability for validating conclusions drawn from open-ended interview data. Field Methods, 12, 179-194, https://doi .org/10.1177/1525822X0001200301.

Kwadijk, J. C. J., and Coauthors, 2010: Using adaptation tipping points to prepare for climate change and sea level rise: A case study in the Netherlands. Wiley Interdiscip. Rev.: Climate Change, 1, 729-740, https:// doi.org/10.1002/wcc.64.

Langsdale, S., A. Beall, E. Bourget, E. Hagen, S. Kudlas, R. Palmer, D. Tate, and W. Werick, 2013: Collaborative modeling for decision support in water resources: Principles and best practices. J. Amer. Water Resour. Assoc., 49, 629-638, https://doi.org/10.1111/jawr.12065.

Lavers, D. A., F. M. Ralph, D. E. Waliser, A. Gershunov, and M. D. Dettinger, 2015: Climate change intensification of horizontal water vapor transport in CMIP5. Geophys. Res. Lett., 42, 5617-5625, https:// doi.org/10.1002/2015GL064672.
Li, D., M. L. Wrzesien, M. Durand, J. Adam, and D. P. Lettenmaier, 2017: How much runoff originates as snow in the western United States, and how will that change in the future? Geophys. Res. Lett., 44, 6163-6172, https://doi.org/10.1002/2017GL073551.

Liu, J., and Coauthors, 2007: Coupled human and natural systems. Ambio, 36, 639-649, https://doi .org/10.1579/0044-7447(2007)36[639:CHANS]2.0 $\mathrm{CO} ; 2$.

Mankin, J. S., D. Viviroli, D. Singh, A. Y. Hoekstra, and N. S. Diffenbaugh, 2015: The potential for snow to supply human water demand in the present and future. Environ. Res. Lett., 10, 114016, https://doi .org/10.1088/1748-9326/10/11/114016.

Maurer, E. P., and H. G. Hidalgo, 2008: Utility of daily vs. monthly large-scale climate data: An intercomparison of two statistical downscaling methods. Hydrol. Earth Syst. Sci., 12, 551-563, https://doi .org/10.5194/hess-12-551-2008.

— - and Coauthors, 2014: An enhanced archive facilitating climate impacts and adaptation analysis. Bull. Amer. Meteor. Soc., 95, 1011-1019, https://doi .org/10.1175/BAMS-D-13-00126.1.

McCabe, G. J., M. P. Clark, and L. E. Hay, 2007: Rain-onsnow events in the western United States. Bull. Amer. Meteor. Soc., 88, 319-328, https://doi.org/10.1175 /BAMS-88-3-319.

McNeeley, S. M., 2014: A “toad's eye” view of drought: Regional socio-natural vulnerability and responses in 2002 in northwest Colorado. Reg. Environ. Change, 14, 1451-1461, https://doi.org/10.1007/s10113-014 $-0585-0$.

_ 2017: Sustainable climate change adaptation in Indian country. Wea. Climate Soc., 9, 393-404, https:// doi.org/10.1175/WCAS-D-16-0121.1.

—, T. A. Beeton, and D. S. Ojima, 2016: Drought risk and adaptation in the interior United States: Understanding the importance of local context for resource management in times of drought. Wea. Climate Soc., 8, 147-161, https://doi.org/10.1175 /WCAS-D-15-0042.1.

Meadow, A. M., D. B. Ferguson, Z. Guido, A. Horangic, G. Owen, and T. Wall, 2015: Moving toward the deliberate co-production of climate science knowledge. Wea. Climate Soc., 7, 179-191, https://doi.org/10.1175 /WCAS-D-14-00050.1.

Mills-Novoa, M., S. L. Borgias, A. Crootof, B. Thapa, R. de Grenade, and C. A. Scott, 2017: Bringing the hydrosocial cycle into climate change adaptation planning: Lessons from two Andean Mountain water towers. Ann. Amer. Assoc. Geogr., 107, 393-402, https://doi.org/10.1080/24694452 .2016.1232618. 
Milly, P. C. D., J. Betancourt, M. Falkenmark, R. M. Hirsch, Z. W. Kundzewicz, D. P. Lettenmaier, and R. J. Stouffer, 2008: Stationarity is dead: Whither water management? Science, 319, 573-574, https:// doi.org/10.1126/science.1151915.

Morss, R. E., O. V. Wilhelmi, M. W. Downton, and E. Gruntfest, 2005: Flood risk, uncertainty, and scientific information for decision making: Lessons from an interdisciplinary project. Bull. Amer. Meteor. Soc., 86, 1593-1601, https://doi.org/10.1175 /BAMS-86-11-1593.

Morway, E. D., R. G. Niswonger, and E. Triana, 2016: Toward improved simulation of river operations through integration with a hydrologic model. Environ. Modell. Software, 82, 255-274, https://doi .org/10.1016/j.envsoft.2016.04.018.

Moser, S. C., and J. A. Ekstrom, 2010: A framework to diagnose barriers to climate change adaptation. Proc. Natl. Acad.Sci. USA, 107, 22 026-22031, https://doi.org /10.1073/pnas.1007887107.

—_ and M. T. Boykoff, 2013: Climate change and adaptation success: The scope of the challenge. Successful Adaptation to Climate Change: Linking Science and Policy in a Rapidly Changing World, S. C. Moser and M. T. Boykoff, Eds., Routledge, 1-33.

Mostert, E., 2018: An alternative approach for socio-hydrology: Case study research. Hydrol. Earth Syst. Sci., 22, 317-329, https://doi.org/10.5194/hess-22-317-2018. Mote, P. W., A. F. Hamlet, M. P. Clark, and D. P. Lettenmaier, 2005: Declining mountain snowpack in western North America. Bull. Amer. Meteor. Soc., 86, 39-49, https://doi.org/10.1175/BAMS-86-1-39.

— of exceptionally low 2015 snowpack in the western United States. Geophys. Res. Lett., 43, 10 980-10988, https://doi.org/10.1002/2016GL069965.

Munroe, J. S., and B. J. C. Laabs, 2013: Temporal correspondence between pluvial lake highstands in the southwestern US and Heinrich Event 1. J. Quat. Sci., 28, 49-58, https://doi.org/10.1002/jqs.2586.

Nava, L. F., C. Brown, K. Demeter, F. Lasserre, M. Milanés-Murcia, S. Mumme, and S. Sandoval-Solis, 2016: Existing opportunities to adapt the Rio Grande/ Bravo basin water resources allocation framework. Water, 8, 291, https://doi.org/10.3390/w8070291.

Niswonger, R. G., E. D. Morway, E. Triana, and J. L. Huntington, 2017: Managed aquifer recharge through off-season irrigation in agricultural regions. Water Resour. Res., 53, 6970-6992, https://doi .org/10.1002/2017WR020458.

NRCS, 2018a: SNOTEL data. Natural Resource Conservation Service, accessed 2 April 2018, www.wcc.nrcs .usda.gov/snow/snotel-data.html.
— 2018 b: Soil Climate Analysis Network (SCAN). Natural Resource Conservation Service, accessed 2 April 2018, www.wcc.nrcs.usda.gov/scan/.

Owen, D., 2014: Overallocation, conflict, and water transfers. Environ. Res. Lett., 9, 091005, https://doi .org/10.1088/1748-9326/9/9/091005.

Padowski, J. C., and J. W. Jawitz, 2012: Water availability and vulnerability of 225 large cities in the United States. Water Resour. Res., 48, W12529, https://doi .org/10.1029/2012WR012335.

Parris, A., G. M. Garfin, K. Dow, S. L. Close, and R. Meyer, Eds., 2016: Climate in Context: Science and Society Partnering for Adaptation. 1st ed. John Wiley \& Sons, 304 pp.

Pierce, D. W., and Coauthors, 2013: The key role of heavy precipitation events in climate model disagreements of future annual precipitation changes in California. J. Climate, 26, 5879-5896, https://doi.org/10.1175 /JCLI-D-12-00766.1.

Polade, S. D., D. W. Pierce, D. R. Cayan, A. Gershunov, and M. D. Dettinger, 2014: The key role of dry days in changing regional climate and precipitation regimes. Sci. Rep., 4, 4634, https://doi.org/10.1038/srep04364.

—, A. Gershunov, D. R. Cayan, M. D. Dettinger, and D. W. Pierce, 2017: Precipitation in a warming world: Assessing projected hydro-climate changes in California and other Mediterranean climate regions. Sci. Rep., 7, 10783, https://doi.org/10.1038 /s41598-017-11285-y.

Prato, T., 2015: Conceptual framework for collaboratively managing coupled human and natural systems under climate change uncertainty. Environ. Nat. Resour. Res., 6, 13-26, https://doi.org/10.5539/enrr .v6n1p13.

Prell, C., K. Hubacek, and M. Reed, 2009: Stakeholder analysis and social network analysis in natural resource management. Soc. Nat. Resour., 22, 501-518, https://doi.org/10.1080/08941920802199202.

Prokopy, L. S., J. S. Carlton, T. Haigh, M. C. Lemos, A. S. Mase, and M. Widhalm, 2017: Useful to usable: Developing usable climate science for agriculture. Climate Risk Manage., 15, 1-7, https://doi.org/10.1016/j .crm.2016.10.004.

Pulwarty, R. S., and R. Maia, 2015: Adaptation challenges in complex rivers around the world: The Guadiana and the Colorado Basins. Water Resour. Manage., 29, 273-293, https://doi.org/10.1007 /s11269-014-0885-7.

Ralph, F. M., and M. D. Dettinger, 2012: Historical and national perspectives on extreme West Coast precipitation associated with atmospheric rivers during December 2010. Bull. Amer. Meteor. Soc., 93, 783-790, https://doi.org/10.1175/BAMS-D-11-00188.1. 
—, P. J. Neiman, and G. A. Wick, 2004: Satellite and CALJET aircraft observations of atmospheric rivers over the eastern North Pacific Ocean during the winter of 1997/98. Mon. Wea. Rev., 132, 1721-1745, https://doi.org/10.1175/1520-0493(2004)132<1721:SA $\mathrm{CAOO}>2.0 . \mathrm{CO} ; 2$.

,,,--- S. I. Gutman, M. D. Dettinger, D. R. Cayan, and A. B. White, 2006: Flooding on California's Russian River: Role of atmospheric rivers. Geophys. Res. Lett., 33, L13801, https://doi.org/10 .1029/2006GL026689.

Reed, M. S., and Coauthors, 2009: Who's in and why? A typology of stakeholder analysis methods for natural resource management. J. Environ. Manage., 90, 19331949, https://doi.org/10.1016/j.jenvman.2009.01.001.

Reheis, M., 1999: Highest pluvial-lake shorelines and Pleistocene climate of the western Great Basin. Quat. Res., 52, 196-205, https://doi.org/10.1006 /qres.1999.2064.

Roco, L., A. Engler, B. Bravo-Ureta, and R. Jara-Rojas, 2014: Farm level adaptation decisions to face climatic change and variability: Evidence from central Chile. Environ. Sci. Policy, 44, 86-96, https://doi .org/10.1016/j.envsci.2014.07.008.

Rossman, G. B., and S. F. Rallis, 2016: An Introduction to Qualitative Research. Learning in the Field. 4th ed. SAGE Publications, $344 \mathrm{pp}$.

Rutz, J. J., W. J. Steenburgh, and F. M. Ralph, 2014: Climatological characteristics of atmospheric rivers and their inland penetration over the western United States. Mon. Wea. Rev., 142, 905-921, https://doi .org/10.1175/MWR-D-13-00168.1.

Singletary, L., and K. Sterle, 2017: Collaborative modeling to assess drought resiliency of snow-fed river dependent communities in the western United States: A case study in the Truckee-Carson river system. Water, 9, 99, https://doi.org/10.3390/w9020099.

—, and —, 2018: Participatory research to assess the climate resiliency of snow-fed river dependent communities: A collaborative modeling case study in the Truckee-Carson river system. Addressing Climate Change at the Community Level in the United States, P. R. Lachapelle and D. Albrecht, Eds., Routledge, 83-98. Sivapalan, M., M. Konar, V. Srinivasan, A. Chhatre, A. Wutich, C. A. Scott, J. L. Wescoat, and I. Rodríguez -Iturbe, 2014: Socio-hydrology: Use-inspired water sustainability science for the Anthropocene. Earth's Future, 2, 225-230, https://doi.org/10.1002 /2013EF000164.

Smit, B., I. Burton, R. J. T. Klein, and J. Wandel, 2000: An anatomy of adaptation to climate change and variability. Climatic Change, 45, 223-251, https://doi .org/10.1023/A:1005661622966.
Spillman, B., 2017: Urgent “big dig” could help Nevada town avert flood disaster. Reno Gazette-Journal, 10 May, www.rgj.com/story/life/outdoors/2017/05/11 /urgent-big-dig-could-help-nevada-town-avert-flood -disaster/317199001/.

Sterle, K., and L. Singletary, 2017: Adapting to variable water supply in the Truckee-Carson river system, western USA. Water, 9, 768, https://doi.org/10.3390 /w9100768.

— — _ and G. Pohll, 2017: Collaboratively modeling water resources in the Truckee-Carson river system). University of Nevada Cooperative Extension, 10 pp., www.unce.unr.edu/publications/.

Stewart, I. T., D. R. Cayan, and M. D. Dettinger, 2005: Changes toward earlier streamflow timing across western North America. J. Climate, 18, 1136-1155, https://doi.org/10.1175/JCLI3321.1.

Stine, S., 1994: Extreme and persistent drought in California and Patagonia during mediaeval time. Nature, 369, 546-549, https://doi.org/10.1038/369546a0.

Swain, D. L., B. Langenbrunner, J. D. Neelin, and A. Hall, 2018: Increasing precipitation volatility in twentyfirst-century California. Nat. Climate Change, 8, 427-433, https://doi.org/10.1038/s41558-018-0140-y.

Thorne, S., 2016: Interpretive Description: Qualitative Research for Applied Practice. 2nd ed. Routledge, $336 \mathrm{pp}$.

Thornton, T. F., and N. Manasfi, 2010: AdaptationGenuine and spurious: Demystifying adaptation processes in relation to climate change. Environ. Soc., 1, 132-155, https://doi.org/10.3167/ares.2010.010107.

Travis, W. R., 2014: Weather and climate extremes: Pacemakers of adaptation? Wea. Climate Extremes, 5-6, 29-39, https://doi.org/10.1016/j.wace.2014 .08 .001 .

Trujillo, E., and N. Molotch, 2014: Snowpack regimes of the western United States. Water Resour. Res., 50, 5611-5623, https://doi.org/10.1002/2013WR014753.

UCAR, 2018: SuomiNet, accessed 2 April 2018, www .suominet.ucar.edu.

U.S. Bureau of Reclamation, 2015: Truckee Basin Study. U.S. Bureau of Reclamation, 310 pp., www.usbr.gov/watersmart/bsp/docs/finalreport /truckee/tbsbasinstudy.pdf.

USGCRP, 2017: Climate Science Special Report. Vol. 1, Fourth National Climate Assessment, D. J. Wuebbles et al., Eds., U.S. Global Climate Research Program, 470 pp., https://science2017.globalchange.gov.

USGS, 2018: USGS Surface-Water Historical Instantaneous Data for Nevada. U.S. Geological Survey, accessed 2 April 2018, https://waterdata.usgs.gov/nv/nwis /uv?referred_module $=$ sw\&search_criteria $=$ search _site_no\&submitted_form=introduction. 
Van Loon, A. F., and Coauthors, 2016: Drought in the Anthropocene. Nat. Geosci., 9, 89-91, https://doi .org/10.1038/ngeo2646.

Verkerk, P. J., and Coauthors, 2017: A participatory approach for adapting river basins to climate change. Water, 9, 958, https://doi.org/10.3390/w9120958.

Vicuna, S., J. A. Dracup, J. R. Lund, L. L. Dale, and E. P. Maurer, 2010: Basin-scale water system operations with uncertain future climate conditions: Methodology and case studies. Water Resour. Res., 46, W04505, https://doi.org/10.1029/2009WR007838.

Voinov, A., and F. Bousquet, 2010: Modelling with stakeholders. Environ. Modell. Software, 25, 1268-1281, https://doi.org/10.1016/j.envsoft.2010.03.007.

—, N. Kolagani, M. K. McCall, P. D. Glynn, M. E. Kragt, F. O. Ostermann, S. A. Pierce, and P. Ramu, 2016: Modelling with stakeholders-Next generation. Environ. Modell. Software, 77, 196-220, https:/doi .org/10.1016/j.envsoft.2015.11.016.

Ware, R. H., and Coauthors, 2000: SuomiNet: A realtime national GPS network for atmospheric research and education. Bull. Amer. Meteor. Soc., 81, 677-694,
https://doi.org/10.1175/1520-0477(2000)081<0677:SA RNGN $>2.3 . \mathrm{CO} ; 2$.

White, A. B., D. J. Gottas, A. F. Henkel, P. J. Neiman, F. M. Ralph, and S. I. Gutman, 2010: Developing a performance measure for snow-level forecasts. J. Hydrometeor., 11, 739-753, https://doi.org/10.1175/2009JHM1181.1. Wilds, L. J., 2014: Water Politics in Northern Nevada: A Century of Struggle. 2nd ed. University of Nevada Press, 139 pp.

Williams, A. P., R. Seager, J. T. Abatzoglou, B. I. Cook, J. E. Smerdon, and E. R. Cook, 2015: Contribution of anthropogenic warming to California drought during 2012-2014. Geophys. Res. Lett., 42, 6819-6828, https://doi.org/10.1002/2015GL064924.

WRCC, 2016: 2008 Western U.S. Local Climate Data. Western Regional Climate Center, accessed 31 March 2018, https://wrcc.dri.edu.

Yung, L., N. Phear, A. DuPont, J. Montag, and D. Murphy, 2015: Drought adaptation and climate change beliefs among working ranchers in Montana. Wea. Climate Soc., 7, 281-293, https://doi.org/10.1175/WCAS -D-14-00039.1.

\section{FROM AMS BOOKS}

\section{"A thoughtful analysis of actions that we need to take to reduce the impacts of extreme weather... a must-read for everyone with an interest in the weather and climate." \\ - FRANKLIN W. NUTTER, \\ President, Reinsurance Association of America}

\section{Living on the Real World: How Thinking and Acting Like Meteorologists Will Help Save the Planet WILLIAM H. HOOKE}

Meteorologists sift through a deluge of information to make predictions every day. Instead of being overwhelmed by the data and possibilities, they focus on small bits of information while using frequent collaboration to make decisions. With climate change a reality, William H. Hooke suggests we look to the way meteorologists operate as a model for how we can solve the twenty-first century's most urgent environmental problems. 